\title{
Selected haematological and biochemical indices in donkeys in the Czech and Slovak Republics
}

\author{
Markéta Sedlinská, Dominika Biricová, Eliška Horáčková, Miroslava Mráčková \\ University of Veterinary and Pharmaceutical Sciences Brno, Faculty of Veterinary Medicine, \\ Equine Clinic Brno, Czech Republic \\ Received December 17, 2015 \\ Accepted August 31, 2016
}

\begin{abstract}
The aim of this study was to establish normal reference values of biochemical and haematological indices of donkeys in the Czech and Slovak Republics. Blood samples were obtained from 112 clinically healthy donkeys (37 males and 75 females). The haematological indices examined were: red blood cells, white blood cells, haemoglobin concentration, haematocrit, mean cell volume, mean cell haemoglobin, mean cell haemoglobin concentration, platelets, segmented neutrophils, neutrophil bands, lymphocytes, monocytes, eosinophils and basophils. The biochemical properties examined were: total protein, albumin, creatinine, alkaline phosphatase, aspartate aminotransferase, creatine kinase, gamma-glutamyl transferase, lactate dehydrogenase, triacylglycerols, cholesterol, calcium, phosphorus, potassium, sodium, lactate. The results reported in this study could serve as reference ranges for the donkey population in the Czech and Slovak Republics.
\end{abstract}

Blood analysis, reference values, Equus asinus

The number of donkeys (Equus asinus) in the Czech and Slovak Republics is growing and, at the same time, there is an increasing demand for the health control of donkeys with reference to the specific climatic conditions of Central Europe. There are a few foreign publications that deal with the assessment of the health indices based on the examination of peripheral blood but, to our knowledge, no similar work has been developed locally. Due to the increased need for the existence of reference haematology and blood biochemistry values in donkeys, we have decided to monitor breeds in the Czech and Slovak Republics. Based on sample findings of drawn peripheral blood, such as reference ranges and observed values, the results are compared with those published in other countries such as Mexico, Brazil, Botswana and Serbia.

Haematology examinations provide valuable data on the metabolic profile, support objective assessment of the state of health and are often helpful in the detection of health disorders at a preclinical stage (Kral and Suchy 2000).

Inappropriate reference limits increase the risk of unnecessary investigations and diagnostic failures. The species, breed, environment, handling and physiological stage can influence serum biochemical and haematological variables (Girardi et al. 2013, 2014).

The aim of this study was to establish reference ranges for biochemistry and haematology profiles of apparently healthy donkeys in Central Europe.

\section{Materials and Methods}

This study was carried out in the Czech and Slovak Republics between the years 2009-2011. Blood samples were collected from 112 clinically healthy donkeys ( 37 males and 75 females) from 26 different owners. Their body condition ranged between 4-9 in the grading system of 1 to 9 ( 1 being very thin and 9 being very fat). The age range of all donkeys was 0.5 to 30 years.

Blood was collected by jugular venipuncture into $10 \mathrm{ml}$ tubes for biochemistry and $2.5 \mathrm{ml}$ EDTA tubes for

Address for correspondence:

MVDr. Markéta Sedlinská, Ph.D.

Equine Clinic, Faculty of Veterinary Medicine

University of Veterinary and Pharmaceutical Sciences Brno

Palackého tř. 1946/1, 612 42, Brno, Czech Republic 
haematology. Samples for biochemistry were allowed to clot at room temperature and serum was separated by centrifugation at $3,000 \mathrm{~g}$ for $15 \mathrm{~min}$. Serum samples were analysed for metabolites: total protein (TP), albumin (ALB), creatinine (CREA), alkaline phosphatase (ALP), aspartate aminotransferase (AST), creatine kinase (CK), gamma-glutamyl transferase (GGT), lactate dehydrogenase (LDH), triacylglycerols (TAG), cholesterol (CHOL), calcium $(\mathrm{Ca})$, phosphorus $(\mathrm{P})$, potassium $(\mathrm{K})$, sodium $(\mathrm{Na})$, lactate (LAC).

All analyses were performed at the Central Clinical Laboratory of the University of Veterinary and Pharmaceutical Sciences Brno using the biochemical analyser DPC Konelab 20i - Thermo Scientific.

The haematological indices examined were: red blood cells (RBC), white blood cells (WBC), haemoglobin concentration $(\mathrm{Hb})$, haematocrit $(\mathrm{HCT})$, mean cell volume $(\mathrm{MCV})$, mean cell haemoglobin $(\mathrm{MCH})$, mean cell haemoglobin concentration (MCHC), platelets (PLT), segmented neutrophils (NEU), neutrophil bands, lymphocytes (LYM), monocytes (MON), eosinophils (EOS) and basophils (BAS). These indices were calculated using the haematological analyser Celltac alpha MEK 6318 - Nihon Kohden.

For each sample, a peripheral blood smear prepared from fresh blood and stained by the Diff- Quick method was examined microscopically for differential leukocyte count.

\section{Results}

The results of biochemical and haematological profiling are listed in Table 1.

\section{Discussion}

The obtained information was compared with data published in other geographical areas of the world, particularly Mexico, Brazil, Botswana, and Serbia (Table 1).

Foreign research is based on a significantly lower number of experimental animals and therefore comparisons can only be indicative, but it does provide interesting information about the dependence of certain blood indices on geographic conditions. Foreign publications provide significantly narrower ranges with respect to the reference number of samples that have been processed. The nearest values which most closely approach the results of this work were in the reference ranges produced in Brazil (Mori et al. 2004).

The reference range of WBC in the blood of donkeys in the Czech and Slovak Republics compared to the values described for most other donkey breeds was higher than those described for Mexican, Brazilian and Botswana donkeys (Mushi et al. 2000; Mori et al. 2004; De Aluja et al. 2006) but lower than that described for Serbian donkeys (Stanisic et al. 2015).

The values of RBC found in this study were similar to those described for Botswana donkeys (Mushi et al. 2000), but lower than those recorded for Mexican, Brazilian, and Serbian donkeys (Mori et al. 2004; De Aluja et al. 2006; Stanisic et al. 2015).

According to published data, the number of platelets found in this study was lower than that recorded for Mexican donkeys (De Aluja et al. 2006), but similar to that described for Botswana donkeys (Mushi et al. 2000).

In this study, the values of TP, ALB and CREA in the blood of donkeys in the Czech and Slovak Republics was higher compared to the values found for Mexican and Serbian donkeys (De Aluja et al. 2006; Stanisic et al. 2015).

The reference values were also compared with the values of individual indices in horses (Table 1). It was in this comparison where the most substantial differences in the measured quantities were found compared to the other above-mentioned groups.

In the case of haematological indices and particularly RBC, haemoglobin and haematocrit, values in the reference range of donkeys are about one third lower than in horses.

The values of biochemical properties show that the difference of creatinine in the reference range of donkeys is considerably higher than that in horses. In the case of AST, $\mathrm{CK}$, GGT, LDH, TAG, Ca, P, K and lactate, reference ranges for donkeys is $\times 2-18$ higher than in horses (Doubek et al. 2007). 
Table 1. Comparison of reference ranges.

\begin{tabular}{|c|c|c|c|c|c|c|}
\hline Analyte & $\begin{array}{c}\text { Horse } \\
\text { (Doubek } \\
\text { et al. 2007) }\end{array}$ & $\begin{array}{l}\text { Czech and } \\
\text { Slovak } \\
\text { Republics }\end{array}$ & $\begin{array}{c}\text { Mexico } \\
\text { (De Aluja } \\
\text { et al. 2006) }\end{array}$ & $\begin{array}{c}\text { Brazil } \\
\text { (Mori } \\
\text { et al. 2004) }\end{array}$ & $\begin{array}{l}\text { Botswana } \\
\text { (Mushi } \\
\text { et al. 2000) }\end{array}$ & $\begin{array}{c}\text { Serbia } \\
\text { (Stanisic } \\
\text { et al. 2015) }\end{array}$ \\
\hline WBC (G/l) & $5.4-14.3$ & $5.61-15.05$ & $10.34-12.6$ & $4.6-11.50$ & $10.16-12.42$ & $11.9-17.0$ \\
\hline $\mathrm{RBC}(\mathrm{T} / \mathrm{l})$ & $6.8-12.9$ & $4.26-8.61$ & $5.7-6.3$ & $5.46-8.17$ & $4.25-9.17$ & $5.9-7.1$ \\
\hline $\mathrm{Hb}(\mathrm{g} / \mathrm{l})$ & $110-190$ & $82.73-165.04$ & $\mathrm{x}$ & $107-145$ & $59.7-154$ & $112.0-125.0$ \\
\hline $\operatorname{HCT}(1 / 1)$ & $0.32-0.53$ & $0.26-0.44$ & $0.34-0.37$ & $0.32-0.44$ & $0.24-0.42$ & $0.340-0.380$ \\
\hline MCV(fl) & $37-58$ & $43.50-67.35$ & $57.4-62.7$ & $48.9-62.7$ & $40.5-69.4$ & $53-57.5$ \\
\hline $\mathrm{MCH}(\mathrm{pg})$ & $12-20$ & $15.67-24.18$ & $\mathrm{x}$ & $17.4-21.6$ & $15.6-23.5$ & $17.1-18.8$ \\
\hline $\mathrm{MCHC}(\mathrm{G} / \mathrm{l})$ & $310-380$ & $330.78-385.14$ & $\mathrm{x}$ & $315-364$ & $314-399$ & $319.5-332.0$ \\
\hline Platelets $(\mathrm{G} / \mathrm{l})$ & $104-368$ & $58.74-376.80$ & $245-1195$ & $\mathrm{x}$ & $63-375$ & $171.0-283.5$ \\
\hline Neutrophil band (\%) & $0-6$ & $0-3.44$ & $\mathrm{x}$ & $0-9.0$ & $\mathrm{x}$ & $\mathrm{x}$ \\
\hline Neutrophil band (G/l) & $0-0.10$ & $0-0.47$ & $\mathrm{x}$ & $0-0.88$ & $\mathrm{x}$ & $\mathrm{x}$ \\
\hline Seg. neutrophils (\%) & $45-70$ & $8.61-67.65$ & $\mathrm{x}$ & $30.5-53.2$ & $\mathrm{x}$ & $\mathrm{x}$ \\
\hline Seg. neutrophils (G/l) & $2.3-8.6$ & $0.32-7.78$ & $1.8-9.2$ & $1.77-5.46$ & $\mathrm{x}$ & $\mathrm{x}$ \\
\hline Lymphocytes (\%) & $20-45$ & $14.24-87.12$ & $\mathrm{x}$ & $35.3-63.5$ & $22-78$ & $\mathrm{x}$ \\
\hline Lymphocytes (G/l) & $1.5-7.7$ & $0.64-10.33$ & $4.6-6$ & $2.14-5.88$ & $\mathrm{x}$ & $4.6-7.5$ \\
\hline Monocytes (\%) & $0-5$ & 0-4.02 & $\mathrm{x}$ & $0-4.6$ & $2-10$ & $\mathrm{x}$ \\
\hline Monocytes (G/l) & $0-0.10$ & $0-0.50$ & $0.04-1.2$ & $0-0.48$ & $\mathrm{x}$ & $\mathrm{x}$ \\
\hline Eosinophils (\%) & $0-4$ & $0-12.24$ & $\mathrm{x}$ & $1-10$ & $4-24$ & $\mathrm{x}$ \\
\hline Eosinophils (G/l) & $0-0.10$ & $0-1.32$ & $0-1.8$ & $0.06-0.92$ & $\mathrm{x}$ & $\mathrm{x}$ \\
\hline Basophils (\%) & $0-2$ & $0-0.79$ & $\mathrm{x}$ & $0-2.9$ & $\mathrm{x}$ & $\mathrm{x}$ \\
\hline Basophils (G/l) & $0-0.30$ & $0-0.08$ & $\mathrm{x}$ & $0-0.17$ & $\mathrm{x}$ & $\mathrm{x}$ \\
\hline $\mathrm{TP}(\mathrm{g} / \mathrm{l})$ & $55-75$ & $58.67-91.16$ & $71.2-74.5$ & $\mathrm{x}$ & $\mathrm{x}$ & $59-70$ \\
\hline $\operatorname{ALB}(g / l)$ & $26-37$ & $23.72-41.24$ & $26.06-28.82$ & $\mathrm{x}$ & $\mathrm{x}$ & $23-29.5$ \\
\hline $\mathrm{CREA}(\mu \mathrm{mol} / \mathrm{l})$ & $106-168$ & $55.95-167.88$ & $83.17-91.92$ & $\mathrm{x}$ & $\mathrm{x}$ & $58.5-84.5$ \\
\hline $\operatorname{ALP}(\mu \mathrm{kat} / \mathrm{l})$ & $2.4-6.6$ & $1.47-5.94$ & $\mathrm{x}$ & $\mathrm{x}$ & $\mathrm{x}$ & $\mathrm{x}$ \\
\hline AST $(\mu \mathrm{kat} / \mathrm{l})$ & $3.7-6$ & $3.51-8.02$ & $3.28-10.2$ & $\mathrm{x}$ & $\mathrm{x}$ & $\mathrm{x}$ \\
\hline $\mathrm{CK}(\mu \mathrm{kat} / \mathrm{l})$ & $0.1-0.5$ & $1.86-9.23$ & $3.01-3.68$ & $\mathrm{x}$ & $\mathrm{x}$ & $\mathrm{x}$ \\
\hline GGT $(\mu \mathrm{kat} / \mathrm{l})$ & $0-0.2$ & $0.43-2.78$ & $0.35-2.95$ & $\mathrm{x}$ & $\mathrm{x}$ & $\mathrm{x}$ \\
\hline LDH $(\mu \mathrm{kat} / \mathrm{l})$ & $1.3-8$ & $3.84-16.13$ & $\mathrm{x}$ & $\mathrm{x}$ & $\mathrm{x}$ & $\mathrm{x}$ \\
\hline TAG $(\mathrm{mmol} / \mathrm{l})$ & $0.10-0.5$ & $0.01-1.91$ & $\mathrm{x}$ & $\mathrm{x}$ & $\mathrm{x}$ & $0.4-1.5$ \\
\hline $\mathrm{CHOL}(\mathrm{mmol} / \mathrm{l})$ & $1.9-3.9$ & $0-4.6$ & X & $\mathrm{x}$ & $\mathrm{x}$ & $0.7-1.3$ \\
\hline $\mathrm{Ca}(\mathrm{mmol} / \mathrm{l})$ & $2.2-3.4$ & $2.3-3.73$ & $2.95-3.09$ & $\mathrm{x}$ & $\mathrm{x}$ & $2.7-3.1$ \\
\hline $\mathrm{P}(\mathrm{mmol} / \mathrm{l})$ & $1-1.8$ & $0.88-2.66$ & $0.61-1.67$ & $\mathrm{x}$ & $\mathrm{x}$ & $0.8-1.2$ \\
\hline $\mathrm{Na}(\mathrm{mmol} / \mathrm{l})$ & $132-146$ & $117.72-150.5$ & $123-168$ & $\mathrm{x}$ & $\mathrm{x}$ & $\mathrm{x}$ \\
\hline $\mathrm{K}(\mathrm{mmol} / \mathrm{l})$ & $2.4-4.7$ & $3.53-6.80$ & $4.19-4.54$ & $\mathrm{x}$ & $\mathrm{x}$ & $\mathrm{x}$ \\
\hline Lactate $(\mathrm{mmol} / \mathrm{l})$ & $1.11-1.76$ & $2.89-12.68$ & X & $\mathrm{x}$ & $\mathrm{x}$ & $\mathrm{x}$ \\
\hline
\end{tabular}

$\mathrm{RBC}=$ red blood cells, $\mathrm{WBC}=$ white blood cells, $\mathrm{Hb}=$ haemoglobin concentration, $\mathrm{HTC}=$ haematocrit, $\mathrm{MCV}=$ mean cell volume $\mathrm{MCH}=$ mean cell haemoglobin, $\mathrm{MCDH}=$ mean cell haemoglobin concentration, $\mathrm{TP}=$ total protein, $\mathrm{ALB}=$ albumin, $\mathrm{CREA}=$ creatinine, $\mathrm{ALP}=$ alkaline phosphatase, $\mathrm{AST}=$ aspartate aminotransferase, $\mathrm{CK}=$ creatine kinase, $\mathrm{GGT}=$ gamma-glutamyl transferase, $\mathrm{LDH}=$ lactate dehydrogenase, $\mathrm{TAG}=$ triacylglycerols, $\mathrm{CHOL}=$ cholesterol, $\mathrm{Ca}=$ calcium, $\mathrm{P}=$ phosphorus, $\mathrm{K}=$ potassium, $\mathrm{Na}=$ sodium

In conclusion, this study established normal reference values of biochemistry and haematology indices for donkeys in Central Europe; these values can be useful for clinical routines and will allow veterinarians to establish appropriate interpretations of laboratory data.

\section{References}

De Aluja AS, Mondragón VLR, Castillo MDA, Ochoa P 2006: Hematological and Biochemical Reference Values in the Donkey (Equus asinus) in Mexico. In: Matthews NS and Taylor TS (Eds): Veterinary Care of Donkeys. International Veterinary Information Service, Ithaca NY (www.ivis.org); A2904.0606

Doubek J, Šlosárková S, Řeháková K, Bouda J, Scheer P, Piperisová I, Tomenendálová J, Matalová E 2007: Interpretation of Basic Biochemistry and Haematology Findings in Animals (In Czech). Noviko a.s., Brno, 102 p. 
Girardi AM, Marques LC, De Toledo CZP, Barboso JC, Maldonado Jr, W, Jorge RLN, Da Silva Nogueira CA 2013: Biochemical profile of the Pêga donkey (Equus asinus) breed: influence of age and sex. Comp Clin Pathol 23: 941-947

Girardi AM, Marques LC, De Toledo CZP, De Campos EF 2014: Hematological variables of the Pêga donkey (Equus asinus) breed: influence of age and sex. Comp Clin Pathol 24: 335-342

Král I, Suchý P 2000: Hematological studies in adolescent breeding cocks. Acta Vet Brno 69: 189-194

Stanisic L, Dimitrijevic V, Simeunovic P, Lakic N, Radovic I, Ivankovic A, Stevanovic J, Stanimirovic Z 2015: Morphological, biochemical and hematological characterization of endangered Balkan donkey breed. Acta Vet-Beograd 64: 125-136

Mori E, Mirandola RMS, Ferreira RR, Oliveira JV, Gacek F, Fernandes WR 2004: Reference Values on Hematologic Parameters of the Brazilian Donkey (Equus asinus) Breed. J Equine Vet Sci 24: 271-276

Mushi EZ, Binta MG, Ndebele RT 1999: Hematological studies on apparently healthy donkeys in Oodi, Kgatleng district Botswana. Proceedings of the workshop of the Animal Traction Network for Eastern and Southern Africa (ATNESA) held 20-24 September 1999, Mpumalanga, South Africa: 344 p. http://www.atnesa.org/ 